J. Nat. Hist. Mus. Vol. 30, 2016-18

$85-101$

\title{
Species diversity, distribution and status of fishes in Chitwan district and adjacent areas, Nepal
}

\author{
Dilip Kumar Jha \\ Department of Aquaculture and Fisheries, Faculty of Animal Science, Veterinary Science \\ and Fisheries, Agriculture and Forestry University, Chitwan, Nepal \\ dkjha.ait@gmail.com
}

\begin{abstract}
Chitwan district is endowed with varied aquatic resources which harbor diverse fish species in central Nepal. A total of 111 fish species were collected from different sampling sites of several tributaries of Trisuli, Rapti and Narayani river systems in Chitwan district and adjacent areas from August 2011 to July 2016. These species belong to 9 orders, 27 families and 72 genera. Among the orders, Cypriniformes had the highest number of species (49\%) followed by Siluriformes (30\%), Perciformes (12\%), Synbranchiformes (3\%), Osteoglossiformes (2\%) while Anguiliformes, Beloniformes, Clupeiformes and Tetraodontiformes represented each by about $1 \%$. Cyprinidae has the highest number of species $(40 \%)$ among the families followed by Sisoridae (12\%), Bagridae (7\%), Cobitidae (5.4\%), Schilbeidae(4.5\%), Channidae (3.6\%), Balitoridae (2.7\%), Mastacembelidae (2.7\%), Siluridae (2.7\%), Notopteridae $(1.8 \%)$, Ambassidae (1.8\%), Nandidae (1.8\%) and Mugilidae (1.8\%). Other families accounted for about $1 \%$ were Anguillidae, Belonidae, Clupeidae, Psilorhynchidae, Anabantidae, Gobiidae, Belontidae, Synbranchidae, Amblycipitidae, Pangasidae, Clariidae, Heteropneustidae, Chacidae and Tetraodontidae. The Botia geto was reported for the first time from Rapti river of Chitwan and adjacent area. Different fish species are naturally maintained in aquatic systems and support livelihoods of the people. Catches of major food fishes are declining due to overexploitation of resources, therefore, appropriate measures are needed at once to maintain and conserve the indigenous stock.
\end{abstract}

Keywords: fish diversity, Botia geto, Pseudolaguvia, Trisuli, Rapti and Narayani Rivers, Chitwan

\section{INTRODUCTION}

Chitwan district lies in the Narayani zone of Central Development Region of Nepal between latitudes $27^{\circ} 20^{\prime}$ to $27^{\circ} 52^{\prime} \mathrm{N}$ and longitudes $83^{\circ} 55^{\prime}$ to $84^{\circ} 52^{\prime} \mathrm{E}$, which covers an area of 2,238 $\mathrm{km}^{2}$. It is a part of Nepalese midlands with monsoon type sub-tropical climate offering huge potential for development of fisheries. It is bounded by Tanahu, Gorkha and Dhading districts in the north, the Parsa district and part of Bihar state of India in the south. It has Nawalparasi district in the west along the Narayani river and the Makwanpur district in the east (fig. 1). Its major portion is flooded during the rainy season which usually extends from June to September. The region is drained by the Gandaki/Narayani river system which ultimately discharges into the Ganga river in India.

Water resources in Chitwan and adjacent districts are drained by the Gandaki river system 
which is one of the three major river systems of Nepal with seven tributaries. It is therefore, called Sapta Gandaki (fig.1) The Kaligandaki, antecedent to Himalayas, is regarded as one of the major tributaries and is joined by the Trisuli at Devghat where it attains the name of Narayani, drains approximately $35000 \mathrm{~km}^{2}$, which runs for approximately $332 \mathrm{~km}$ in Nepal before spilling into the Ganga river of India (Smith et al. 1996; Edds, 1986). In addition, Marsyangdi, Seti, Budhigandaki, Madi and Myagdi rivers are also considered as major tributaries of Gandaki river system. The Rapti river flows from the east to west direction dissecting the whole Chitwan valley in almost two parts and join the Narayani river at Golaghat in the Narayani municipality (Singh, 2013). Faunal composition on the natural system of the Narayani river is affected by interference of barrage in Nepal-India border at Tribenighat of Nawalparasi district (Smith et al., 1996; Rajbanshi, 2002; Gubhaju, 2012; Gurung, 2012). The Kaligandaki/ Trisuli/Narayani systems sever through all of Nepal's varied geographical zones and thus present an excellent opportunity to examine the fish distribution along an impressive altitudinal gradient.

Considerable studies on the fish diversity and distribution of the Trisuli/Gandaki/Narayani river systems have been undertaken by many researchers (Shrestha, 1981, 1990, 1994, 2004, 2008, 2012; Jha, et al., 1989, 2014; Dhital \& Jha, 2002; Rajbanshi, 2002, 2012; Edds, 1986 a \& b, 1993; Ng, 2003; Shrestha \& Edds, 2012). Earlier, Shrestha (1981) reported 23 species fish from the Gandaki river system. Edds (1986a \& b) recorded 107 and 111 species of fish from Chitwan National Park and the Kaligandaki-Narayani river system respectively. Jha et al. $(1989,2014)$ and Dhital \& Jha (2002) collected 68, 108 and 69 species from the NarayaniRapti river system in Chitwan respectively. Moreover, Shrestha (1990) and Rajbanshi (2002) reported 88 and 85 species from the Narayani river respectively.

Major rivers and their tributaries support a wide range of ichthyofaunal diversity and service to society (Gurung, 2016). The aquatic resources in Chitwan and the adjacent areas have vital fish stocks which are greatly affected by alteration of habitat and their overexploitation. There is a need to assess species distribution in different geographic locations for proper conservation. Therefore, an effort has been made to investigate the fish diversity of the Trisuli/ Gandaki/Rapti/Narayani river systems in Chitwan and adjacent areas.

\section{MATERIALS AND METHODS}

\section{Study area}

Chitwan district lies in the Central Development Region of Nepal. This district features a subtropical weather along with monsoon climate and is drained by the Trisuli, Gandaki/ Narayani river systems which ultimately discharge into the Ganga river in India. Its upper northern part is drained by Trisuli river which received Marsyangdi and Kaligandaki rivers at Muglin and Devghat respectively. From Devghat it named Narayani river which forms the western border with Nawalparasi district. The Narayani river extends widely and collects Rapti and Rew rivers along with a large number of tributaries of eastern Chitwan as Khageri, Kayar, Ladari, Pampa, Dhongre, Martal and Lothar (fig.1). These aquatic resources were studied in Chitwan along with adjacent areas in Makwanpur and Nawalparasi districts from August 2011 to July 2016. 


\section{Sampling sites}

The study area (fig.1) was divided into ten sampling sites: I= Trishuli river at Kuringhat, II= Trishuli and Marsyangadi confluence at Muglin, III= Narayani river (Trishuli and Kaligandaki confluence) at Devghat and Narayanghat, IV= North - eastern bank of Narayani river at Shivaghat, Kabreghat and Kharkhareghat, $V=$ Eastern and western bank of Narayani river at Koleghat of Chitwan and Nawalparasi, VI= Rapti river at Meghauli and Rapti -Narayani confluence at Golaghat of Narayani municipality, Chitwan, VII= Khageri river, Burhi Rapti, and Lothar river in eastern Chitwan, VIII= Manhari-Rapti confluence in Makwanpur district, IX= Rew river and its feeder streams at Madi in Chitwan National Park, and X= Western bank of Narayani River at Tribenighat of Nawalparasi district. Geographical coordinates of these sites are given in table 1 .

TABLE 1. Geographical coordinates of different study sites.

\begin{tabular}{|c|c|c|c|c|}
\hline Site & Location & Longitude & Latitude & Elevation (m) \\
\hline I & Kuringhat (Trishuli river) & $27^{\circ} 52^{\prime} 09^{\prime \prime} \mathrm{N}$ & $81^{\circ} 37^{\prime} 55^{\prime \prime} \mathrm{E}$ & 272 \\
\hline II & $\begin{array}{l}\text { Muglin (Trishuli-Marsyangdi } \\
\text { confluence) }\end{array}$ & $27^{\circ} 51^{\prime} 26^{\prime \prime} \mathrm{N}$ & $84^{\circ} 33^{\prime} 35^{\prime \prime} \mathrm{E}$ & 252 \\
\hline III & $\begin{array}{l}\text { Devghat (Narayani and } \\
\text { Kaligandaki confluence) }\end{array}$ & $27^{\circ} 44^{\prime} 28^{\prime \prime} \mathrm{N}$ & $84^{\circ} 25^{\prime} 24^{\prime \prime} \mathrm{E}$ & 191 \\
\hline IV & $\begin{array}{l}\text { Shivaghat, north- eastern bank of } \\
\text { Narayani river }\end{array}$ & $27^{\circ} 40^{\prime} 46^{\prime \prime} \mathrm{N}$ & $84^{\circ} 22^{\prime} 38^{\prime \prime} \mathrm{E}$ & 183 \\
\hline V & $\begin{array}{l}\text { Koleghat (eastern and western } \\
\text { bank of Narayani river) }\end{array}$ & $27^{\circ} 41^{\prime} 27^{\prime \prime} \mathrm{N}$ & $84^{\circ} 21^{\prime} 42^{\prime \prime} \mathrm{E}$ & 176 \\
\hline VI & $\begin{array}{l}\text { Golaghat, Meghauli (Narayani } \\
\text { and Rapti Confluence) }\end{array}$ & $27^{\circ} 33^{\prime} 50^{\prime \prime} \mathrm{N}$ & $84^{\circ} 09^{\prime} 29^{\prime \prime} \mathrm{E}$ & 142 \\
\hline VII & $\begin{array}{l}\text { Lothar (Lothar and Rapti } \\
\text { confluence) }\end{array}$ & $27^{\circ} 33^{\prime} 45^{\prime \prime} \mathrm{N}$ & $84^{\circ} 42^{\prime} 32^{\prime \prime} \mathrm{E}$ & 245 \\
\hline VIII & $\begin{array}{l}\text { Manahari (Manahari and Rapti } \\
\text { confluence) }\end{array}$ & $27^{\circ} 31^{\prime} 38^{\prime \prime} \mathrm{N}$ & $84^{\circ} 46^{\prime} 46^{\prime \prime} \mathrm{E}$ & 278 \\
\hline IX & Madi (Reu river) & $27^{\circ} 27^{\prime} 52^{\prime \prime} \mathrm{N}$ & $84^{\circ} 21^{\prime} 14^{\prime \prime} \mathrm{E}$ & 182 \\
\hline$x$ & $\begin{array}{l}\text { Trivenighat (Near India Border at } \\
\text { dam site) }\end{array}$ & $27^{\circ} 26^{\prime} 08^{\prime \prime} \mathrm{N}$ & $83^{\circ} 54^{\prime} 38^{\prime \prime} \mathrm{E}$ & 116 \\
\hline
\end{tabular}




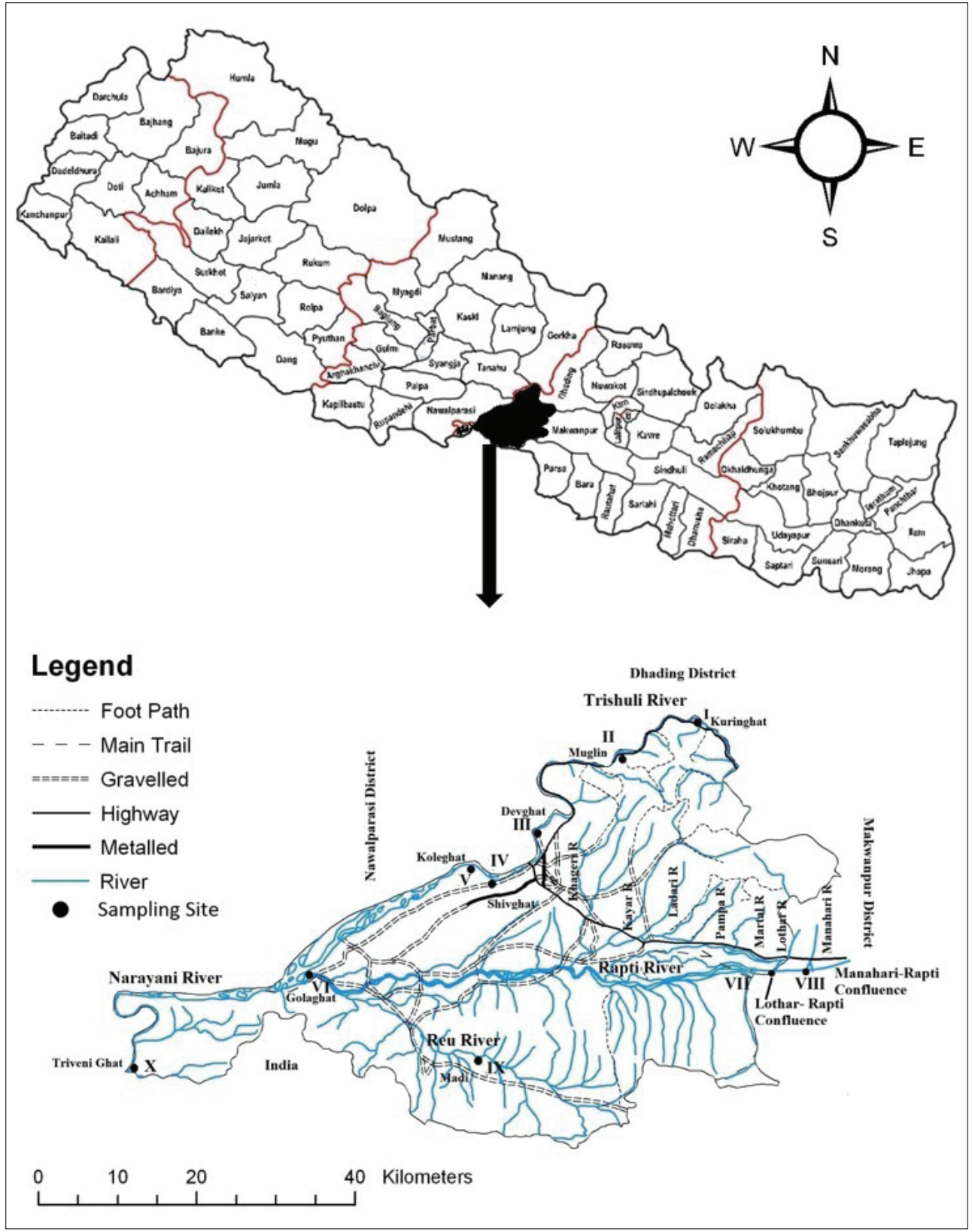

FIG. 1. Map of Nepal showing Chitwan district and adjacent areas along with the Narayani river and its tributaries. Black dots indicate sampling sites.

Sample collection, preservation and identification 
Fish samples were collected from different selected sites with the help of local fishermen. Different types of fishing gears such as cast net, gill net, drag net and fish traps were used for the collection of fish specimens from these sites. Usually cast net was frequently applied. Sampling station was maintained within each study site to maximize fish collection. Ecological features of the fish habitat and color of fish species were recorded throughout collection. These specimens were preserved in $10 \%$ formalin. One milliliter pure glycerin per liter of $10 \%$ formalin was used to protect specimens from quick fading of their color. The large specimens were incised lengthwise along the abdomen while the smaller ones were directly put into the formalin. The fish were kept upside down to avoid any damage to caudal fin in the container.

For species identification, counts of lateral line scales and fin rays as well as measurement of body were made according to the system developed by Talwar \& Jhingran (1991), Jayaram (1999) and Shrestha (1981, 2001, and 2008). Most of the identified preserved specimens are available from Department of Aquaculture and Fisheries, Rampur, Chitwan while some of the specimens are placed in Manahari Development Institute (MDI), Hetaunda, Nepal. The genera under their respective families and the species under their respective genera have been arranged alphabetically

\section{RESULTS AND DISCUSSION}

\section{Fish diversity, composition, distribution and status}

A total of 111 species belonging to 9 orders, 27 families, 71 genera were collected across all the major tributaries of river Narayani in Chiwan district and its adjacent areas in Nawalparasi and Makwanpur districts. Among the orders, Cypriniformes had the highest number of species $(49 \%)$ followed by Siluriformes $(30 \%)$, Perciformes $(12 \%)$, Synbranchiformes (3\%) and Osteoglossiformes (2\%) while Anguilliformes, Beloniformes, Clupeiformes and Tetraodontiformes represented each by about $1 \%$ (fig. 2).

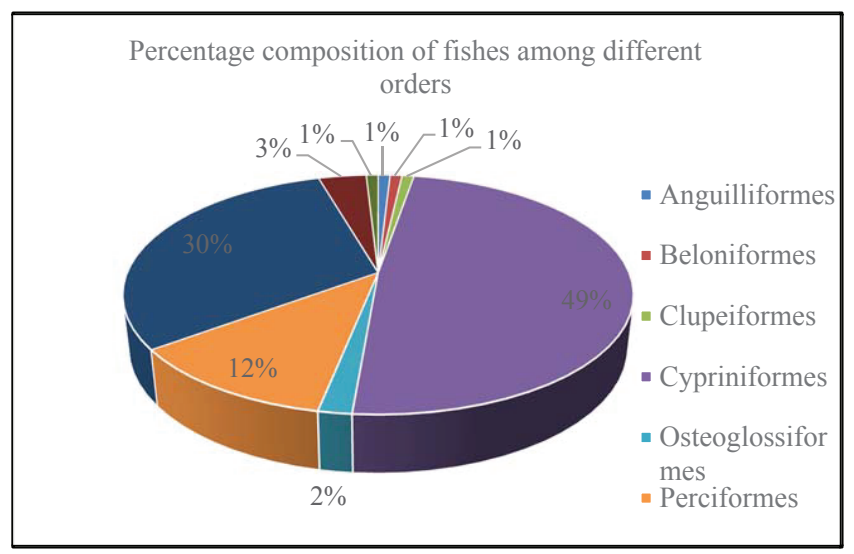

FIG. 2. Percentage composition of fishes among different orders.

Similarly, Cyprinidae was the highest number of species (40\%) among the families followed by Sisoridae (12\%), Bagridae (7\%), and Cobitidae (5.4\%). Other families accounted for about 
$1 \%$ with each of single species were Anguillidae, Belonidae,Clupeidae, Psilorhynchidae, Anabantidae, Gobiidae, Belontidae, Synbranchidae, Amblycipitidae, Pangasidae, Clariidae, Heteropneustidae, Chacidae and Tetraodontidae (table 2).

Number of fishes under different families is given in fig. 3. Taxonomic position, local name, distribution of fishes in different sites and status of fish species are listed in table 2.

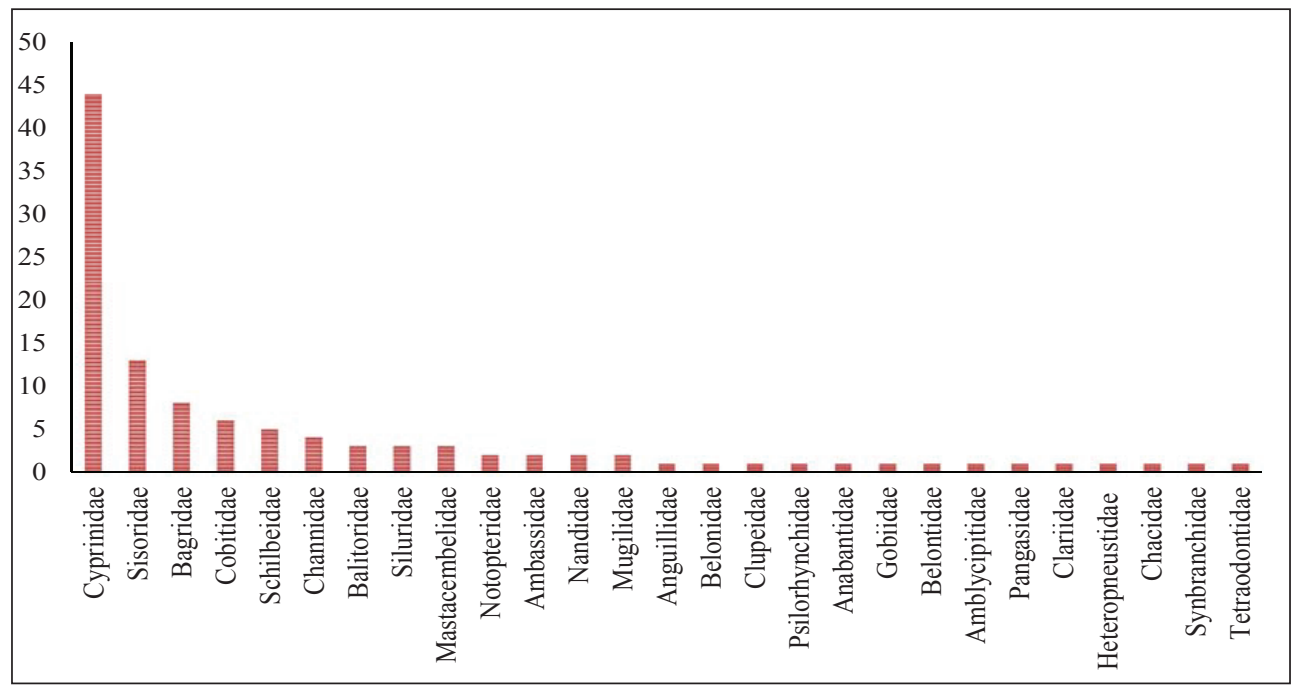

FIG. 3. Number of fish species under different families. 
TABLE 2. Systematic position, distribution and status of fish species in the rivers of Chitwan and adjacent areas.

\begin{tabular}{|c|c|c|c|}
\hline $\begin{array}{l}\text { Order, sub-order, family, sub-family, } \\
\text { genus and species }\end{array}$ & Local name & $\begin{array}{c}\text { Distribution } \\
\text { of fishes } \\
\text { in different } \\
\text { sites }\end{array}$ & Status \\
\hline \multicolumn{4}{|l|}{ I. Order: Anguilliformes } \\
\hline \multicolumn{4}{|l|}{ Suborder: Anguilloidei } \\
\hline \multicolumn{4}{|l|}{ Family: Anguillidae } \\
\hline 1. Anguilla bengalensis (Gray) & Rajbam & I to $X$ & $\mathrm{R}, \mathrm{M}$ \\
\hline \multicolumn{4}{|l|}{ II. Order: Beloniformes } \\
\hline \multicolumn{4}{|l|}{ Suborder: Belonoidei } \\
\hline \multicolumn{4}{|l|}{ Family: Belonidae } \\
\hline 1. Xenentodon cancila (Ham.) & Kauwamachha & I to $X$ & C, LM \\
\hline \multicolumn{4}{|l|}{ III. Order: Clupeiformes } \\
\hline \multicolumn{4}{|l|}{ Suborder: Clupeioidei } \\
\hline \multicolumn{4}{|l|}{ Family: Clupeidae } \\
\hline 1. Gudusia chapra (Ham.) & Suiya & $x$ & $\mathrm{R}$ \\
\hline \multicolumn{4}{|l|}{ IV. Order: Cypriniformes } \\
\hline \multicolumn{4}{|l|}{ Family: Cyprinidae } \\
\hline \multicolumn{4}{|l|}{ Subfamily:Cyprininae } \\
\hline 1. Catla catla (Ham.) & Vakura & VI \& X & $\mathrm{R}$ \\
\hline 2. Chagunius chagunio (Ham.) & Chaurahi & II to IV & $\mathrm{C}$ \\
\hline 3. Cirrhinus mrigala mrigala (Ham.) & Naini & $I V, V I \& X$ & $\mathrm{R}$ \\
\hline 4. Cirrhinus reba (Ham.) & Rewa & IV to $X$ & $\mathrm{C}$ \\
\hline 5. Cyprinion semiplotus (Mc-Clelland) & Chepti & IV to $X$ & $\mathrm{R}, \mathrm{M}$ \\
\hline 6. Labeo angra (Ham.) & Basarhi & III to $X$ & C, LM \\
\hline 7. Labeo bata (Ham.) & Bata & VI to $\mathrm{X}$ & C, LM \\
\hline 8. Labeo calbasu (Ham.) & Karaunchh & III to $X$ & C, LM \\
\hline 9. Labeo dero (Ham.) & Gardi & I to $X$ & $\mathrm{C}$ \\
\hline 10. Labeo gonius (Ham. & Kursa & VI to $X$ & UC \\
\hline 11. Labeo rohita (Ham.) & Rohu & IV to $X$ & UC \\
\hline 12. Labeo pangusia (Ham.) & Kalaunchh & I to $X$ & $\mathrm{R}$ \\
\hline 13. Neolissochilus hexagonolepis (Mc-Cl.) & Katle & I to $X$ & $\mathrm{R}$ \\
\hline 14. Osteobrama cotio cotio (Ham.) & Gurda & $\mathrm{X}$ & $\mathrm{C}$ \\
\hline
\end{tabular}




\begin{tabular}{|c|c|c|c|}
\hline 15. Puntius chola (Ham.) & Sidhare & IV to $X$ & $\mathrm{C}$ \\
\hline 16. Puntius conchonius (Ham.), & Sidhare & IV to $X$ & UC \\
\hline 17. Puntius phutunio (Ham.) & Sidhare & $\mathrm{X}$ & $\mathrm{R}$ \\
\hline 18. Puntius sarana sarana (Ham.) & Sidhare & IV to $X$ & UC \\
\hline 19. Puntius sophore (Ham.) & Sidhare & IV to $X$ & $\mathrm{C}$ \\
\hline 20. Puntius ticto (Ham.) & Tikuliasidhare & IV to $X$ & C \\
\hline 21. Tor Putitora (Ham.) & Sahar & I to VIII & $\mathrm{R}, \mathrm{M}$ \\
\hline 22. Tor Tor (Ham.) & Sahar & I to VIII & $\mathrm{R}, \mathrm{M}$ \\
\hline \multicolumn{4}{|l|}{ Subfamily: Cultrinae } \\
\hline 23. Salmostoma acinaces (Val.) & Chelha & VI to $X$ & C \\
\hline 24. Salmostoma bacaila (Ham.) & Chelha & $\mathrm{X}$ & UC \\
\hline 25. Securicula gora (Ham.) & Chelha & $x$ & UC \\
\hline \multicolumn{4}{|l|}{ Subfamily: Rasborinae } \\
\hline 26. Amblypharyngodon mola (Ham.) & Dhawai & $x$ & $\mathrm{R}$ \\
\hline 27. Aspidoparia morar (Ham.) & Chepua & III to $X$ & $\mathrm{C}$ \\
\hline 28. Barilius barna (Ham.) & Faketa & I, II \& V & C \\
\hline 29. Barilius barila (Ham.) & Faketa & $\mathrm{I}, \mathrm{II}$ to $\mathrm{V}$ & $\mathrm{R}$ \\
\hline 30. Barilius bendelisis (Ham.) & Khasre & I to VIII & C \\
\hline 31. Barilius tileo (Ham.) & Faketa & $\mathrm{IV} \& \mathrm{VI}$ & C \\
\hline 32. Barilius vagra (Ham.) & Faketa & $V \& X$ & RS \\
\hline 33. Brachydanio rerio (Ham.) & Dedhwa & IV \& X & RS \\
\hline 34. Danio aequipinnatus (Ham.) & Pataki & IV to VIII & RS \\
\hline 35. Danio devario (Ham.) & Pataki & IV to VIII & RS \\
\hline 36. Esomus danricus (Ham.) & Dedhwa & IV to $X$ & C \\
\hline 37. Parluciosoma daniconius (Ham.) & Dedhwa & IV to $X$ & $\mathrm{C}$ \\
\hline 38. Raiamas bola (Ham.) & Galara & IV to $X$ & C \\
\hline 39. Raiamas guttatus (Ham.) & Hasta & IV to $X$ & $\mathrm{C}$ \\
\hline 40. Schizothorichthys progastus (McCl.) & Asla & I to IV & $\mathrm{R}$ \\
\hline 41. Schizothorichthys richardsonii (Gray) & Asla & I to IV & $\mathrm{R}$ \\
\hline \multicolumn{4}{|l|}{ Subfamily:Garrinae } \\
\hline 42. Crossocheilus latius latius (Ham.) & Budhuna & IV to $\mathrm{VI}$ & C \\
\hline 43. Garra annandalei (Hora) & Budhuna & III to VIII & $U$ \\
\hline 44. Garra gotyla (Gray) & Nakurobudhuna & III to VIII & C \\
\hline Family: Psilorhynchidae & & & \\
\hline
\end{tabular}




\begin{tabular}{|c|c|c|c|}
\hline $\begin{array}{l}\text { 45. Psilorhynchus pseudecheneis (Menon } \\
\text { \& Datta) }\end{array}$ & Tite & I to IV & $R$ \\
\hline \multicolumn{4}{|l|}{ Family: Balitoridae } \\
\hline \multicolumn{4}{|l|}{ Subfamily: Nemacheilinae } \\
\hline 46. Acanthocobitis botia (Ham.) & Goira & IV to $\mathrm{V}$ & C \\
\hline 47. Nemacheilus corica (Ham.) & Gadela & I to IV & UC \\
\hline 48. Schistura beavani (Gunther) & Goira & IV to $\mathrm{V}$ & C \\
\hline \multicolumn{4}{|l|}{ Family: Cobitidae } \\
\hline \multicolumn{4}{|l|}{ Subfamily: Cobitinae } \\
\hline 49. Lepidocephalus guntea (Ham.) & Nakati & IV to $X$ & $\mathrm{C}$ \\
\hline 50. Somileptus gongota (Ham.) & Goira & IV to $X$ & $\mathrm{R}$ \\
\hline \multicolumn{4}{|l|}{ Subfamily: Botiinae } \\
\hline 51. Botia almorhae (Gray) & Baghe & III to $X$ & $\mathrm{R}$ \\
\hline 52. B.dario (Ham.) & Baghe & III to $X$ & $\mathrm{R}$ \\
\hline 53. B. geto (Ham.) & Baghe & VII to VIII & $\mathrm{R}$ \\
\hline 54. B. lohachata (Chauduri) & Baghe & III to $X$ & UC \\
\hline \multicolumn{4}{|l|}{ V. Order: Osteoglossiformes } \\
\hline \multicolumn{4}{|l|}{ Suborder: Notopteroidei } \\
\hline \multicolumn{4}{|l|}{ Family: Notopteridae } \\
\hline 1. Notopterus notopterus (Pallas) & Patra & IV to $X$ & $\mathrm{C}$ \\
\hline 2. Chitala chitala (Ham.) & Moi & IV to $X$ & $\mathrm{R}$ \\
\hline \multicolumn{4}{|l|}{ VI. Order: Perciformes } \\
\hline Suborder: Percoidei & & IV to $X$ & \\
\hline \multicolumn{4}{|l|}{ Family: Ambassidae } \\
\hline 1. Chanda nama (Ham.) & Chuna & IV to $X$ & $\mathrm{C}$ \\
\hline 2. Parambassis ranga (Ham.) & Chanarbiju & IV to $X$ & $\mathrm{C}$ \\
\hline \multicolumn{4}{|l|}{ Family: Nandidae } \\
\hline \multicolumn{4}{|l|}{ Subfamily:Nandinae } \\
\hline 3. Nandus nandus (Ham.) & Dhedhari & IV to $X$ & C \\
\hline \multicolumn{4}{|l|}{ Subfamily:Badinae } \\
\hline 4. Badis badis (Ham.) & Khesaki & $x$ & $\mathrm{R}$ \\
\hline \multicolumn{4}{|l|}{ Suborder: Anabantoidei } \\
\hline \multicolumn{4}{|l|}{ Family: Anabantidae } \\
\hline 5. Anabas testudineus (Bloch) & Kabai & $\mathrm{X}$ & $\mathrm{R}$ \\
\hline
\end{tabular}




\begin{tabular}{|c|c|c|c|}
\hline \multicolumn{4}{|l|}{$\begin{array}{l}\text { Suborder:Gobioidei } \\
\text { Family: Gobiidae } \\
\text { Subfamily: Gobiinae }\end{array}$} \\
\hline 6. Glossogobius giuris (Ham.) & Bulla & IV to $X$ & $\mathrm{C}$ \\
\hline \multirow{2}{*}{\multicolumn{4}{|c|}{$\begin{array}{l}\text { Suborder: Mugiloidei } \\
\text { Family: Mugilidae }\end{array}$}} \\
\hline & & & \\
\hline 7. Rhinomugil corsula (Ham.) & Thadiya & $\mathrm{X}$ & $\mathrm{R}$ \\
\hline 8. Sicamugil cascasia (Ham.) & Hurra & $x$ & $\mathrm{R}$ \\
\hline \multirow{2}{*}{\multicolumn{4}{|c|}{$\begin{array}{l}\text { Family: Belontidae } \\
\text { Subfamily:Trichogasterinae }\end{array}$}} \\
\hline & & & \\
\hline 9. Colisa fasciatus (Bloch \& Schneider) & Kotari & IV to $X$ & $\mathrm{C}$ \\
\hline \multirow{2}{*}{\multicolumn{4}{|c|}{$\begin{array}{l}\text { Sub-order: Channoidae } \\
\text { Family: Channidae }\end{array}$}} \\
\hline & & & \\
\hline 10. Channa marulius (Ham.) & Saura & IV to $X$ & $\mathrm{C}$ \\
\hline 11. Channa orientalis (BI. \& Schn.) & Bhoti & IV to $X$ & $\mathrm{C}$ \\
\hline 12. Channa punctatus (Bloch) & Hile & IV to $X$ & $\mathrm{C}$ \\
\hline 13. Channa striatus (Bloch) & Saura & IV to $X$ & $\mathrm{C}$ \\
\hline \multirow{2}{*}{\multicolumn{4}{|c|}{$\begin{array}{l}\text { VII. Order: Siluriformes } \\
\text { Family: Amblycipitidae }\end{array}$}} \\
\hline & & & \\
\hline 1. Amblyceps mangois (Ham.) & Paharisinghi & IV to $X$ & $\mathrm{C}$ \\
\hline Family: Bagridae & & IV to $\mathrm{X}$ & \\
\hline 2. Aorichthys aor (Ham.) & Kubratengar & IV to $X$ & $\mathrm{C}$ \\
\hline 3. Aorichthys seenghala (Sykes) & Kanti & IV to $X$ & C \\
\hline 4. Mystus bleekeri (Day) & Tengasi & IV to $X$ & RS \\
\hline 5. Mystus cavasius (Ham.) & Tengara & IV to $X$ & RS \\
\hline 6. Mystus menoda (Ham.) & Tengara & $\mathrm{x}$ & $\mathrm{R}$ \\
\hline 7. Mystus tengara (Ham.) & Tengara & IV to $X$ & $\mathrm{C}$ \\
\hline 8. Mystus vittatus (Bloch) & Tengana & IV to $X$ & C \\
\hline 9. Rita rita (Ham.) & Tengar & IV to $X$ & UC \\
\hline Family: Siluridae & & IV to $X$ & \\
\hline 10.Ompok bimaculatus (Bloch) & Lodara & IV to $X$ & $\mathrm{C}$ \\
\hline 11. Ompok pabda (Ham.) & Nanaria & IV to $X$ & $\mathrm{R}$ \\
\hline 12. Wallago attu (BI. \& Schn.) & Barari & IV to $X$ & C \\
\hline
\end{tabular}




\begin{tabular}{|c|c|c|c|}
\hline \multicolumn{4}{|l|}{$\begin{array}{l}\text { Family: Schilbeidae } \\
\text { Subfamily:Ailiinae }\end{array}$} \\
\hline 13. Ailia coila (Ham.) & Jalkapoor & $\mathrm{V}$ to $\mathrm{X}$ & $\mathrm{R}$ \\
\hline \multicolumn{4}{|l|}{ Subfamily:Schilbeinae } \\
\hline 14. Clupisoma garua (Ham.) & Jalkapoor & $V$ to $X$ & C \\
\hline 15. Eutropiichthys vacha (Ham.) & Suha & IV to $X$ & $\mathrm{R}$ \\
\hline 16. Eutropiichthys murius(Ham.) & Jalkapoor & IV to $X$ & $\mathrm{R}$ \\
\hline 17. Pseudeutropius atherinoides (Bloch) & Jalkapoor & IV to VII & $\mathrm{C}$ \\
\hline \multicolumn{4}{|l|}{ Family: Pangasidae } \\
\hline 18. Pangasius pangasius (Ham.) & Jalkapoor & $x$ & $\mathrm{R}$ \\
\hline \multicolumn{4}{|l|}{ Family: Sisoridae } \\
\hline 19. Bagarius bagarius (Ham.) & Gonch & I to $X$ & UC \\
\hline 20. Bagarius yarrellii (Sykes) & Gonch & I to $X$ & UC \\
\hline 21. Gagata cenia (Ham.) & Datkitari & $V$ to $X$ & UC \\
\hline 22. Glyptothorax cavia (Ham.) & Kapre & II to IV & $\mathrm{R}$ \\
\hline 23. Glyptothorax indicus (Talwar) & Kursimlo & III to $\mathrm{V}$ & $\mathrm{R}$ \\
\hline 24. Glyptothorax pectinopterus (McCl.) & Kapre & IV to $X$ & $\mathrm{R}$ \\
\hline 25. Glyptothorax telchitta (Ham.) & Chepti & IV to $X$ & $\mathrm{C}$ \\
\hline 26. Hara hara (Ham.) & Datkitari & VI to VIII & $\mathrm{R}$ \\
\hline 27. Nangra viridescens (Ham.) & Katenga & VIII \& X & $\mathrm{R}$ \\
\hline 28. Pseudecheneis sulcatus (McCl.) & Vedra & I to $\mathrm{V}$ & UC \\
\hline 29. Pseudolaguvia kapuri (Tilak \& Husain) & Kapre & VI to VII & $\mathrm{R}$ \\
\hline 30. Pseudolaguvia ribeiroi (Hora) & Patekapre & VI to VII & $\mathrm{R}$ \\
\hline 31. Sisor rhabdophorus (Ham) & Chheparomachha & $x$ & $\mathrm{R}$ \\
\hline \multicolumn{4}{|l|}{ Family: Clariidae } \\
\hline 32.Clarias batrachus (Linnaeus) & Mangur & IV to $X$ & $\mathrm{C}$ \\
\hline \multicolumn{4}{|l|}{ Family: Heteropneustidae } \\
\hline 33. Heteropneustes fossilis (Bloch) & Singhi & IV to $X$ & C \\
\hline \multicolumn{4}{|l|}{ Family: Chacidae } \\
\hline 34. Chaca chaca (Ham.) & Kirkire & $x$ & $\mathrm{R}$ \\
\hline \multicolumn{4}{|l|}{$\begin{array}{l}\text { VIII. Order: Synbranchiformes } \\
\text { Suborder:Synbranchoidei } \\
\text { Family: Synbranchidae }\end{array}$} \\
\hline 1. Monopterus cuchia (Ham.) & Andhwabam & IV to $X$ & $\mathrm{C}$ \\
\hline
\end{tabular}




\begin{tabular}{|l|l|c|c|}
\hline $\begin{array}{l}\text { Suborder: Mastacembeloidei } \\
\text { Family: Mastacembelidae } \\
\text { Subfamily:Mastacembelinae }\end{array}$ & & IV to X & \\
\hline 2. Macrognathus aral (BI. \& Schn.) & Chuchebam & IV to X & C \\
\hline 3. Macrognathus pancalus (Ham.) & Dharebam & IV to X & RS \\
\hline 4. Mastacembelus armatus (Lacepede) & Bam & IV to X & RS \\
\hline $\begin{array}{l}\text { IX. Order: Tetraodontiformes } \\
\text { Suborder:Tetraodontoidei } \\
\text { Family:Tetraodontidae } \\
\text { Subfamily:Tetraodontinae }\end{array}$ & & & \\
\hline 1. Tetraodon cutcutia (Ham.) & & & \\
\hline
\end{tabular}

The status of each species is given as: common (C), uncommon (UC), rare (R), resident (RS), migratory (M) and local migrant (LM). Localities I to VIII are given as mentioned in the 'Materials and Methods'. Common: Frequently noted during sampling period; Uncommon: Very few represent in the sample; Resident: Never migrate according to local fishermen; Rare: Very few, sometimes absent; only repeated sampling reveal the presence of the species.

The Trisuli/Rapti/Narayani river ecosystem supports diverse stock of carps, catfishes, perches, featherbacks, eels, gobies, puffers, yellowtails, loaches, mullets and so on. Upper parts of these aquatic resources are dominated by important coldwater fishes such as Schizothorax sp., Schizothoraichthys spp., Neolissocheilus hexagonolepis, Tor spp. and Bagarius spp. The middle and lower parts are chiefly inhabited by mixed group of fishes like carps, catfishes, perches, snakeheads, featherbacks and eels (table 2). Out of 111 species, common (49), uncommon (14) rare (40) and resident (8) were observed (fig. 4). Among these, Barilius bendelisis, Puntius spp., Esomus sp., Mystus spp., Glossogobius sp., Monopterus cuchia, Macrognathus sp., Notopterus notopterus, Aorichthys spp. and Channa spp. were frequently observed while some species of carps, loaches and catfishes were seen uncommonly and rare also (table 2). Further, Amblypharyngodon mola, Chaca chaca, Rhinomugil corsula and Anabas testudineus were also very rare and collected from canals in Nawalparasi district only. Though Amblypharyngodon mola was available in some farmer's ponds of Chitwan, the Anabas testudineus was not seen in the Chitwan district. The Status of fish species of the Narayani river system is given in fig. 4. Most of these species have high market value and preferred by the people. However, they are caught only from the wild and have not yet been cultured with some exception. 


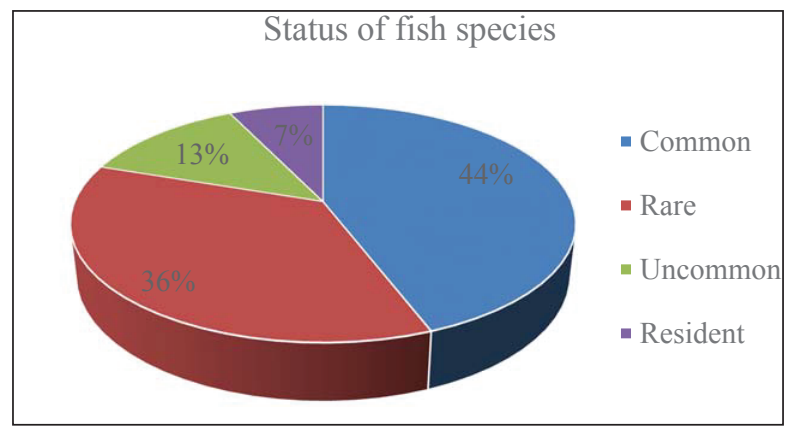

FIG. 4. Status of fish species in the aquatic resources of Chitwan and adjacent areas.

In Nepal, 230 indigenous fishes have been reported from major rivers along with their feeder streams and scores of lakes and reservoirs (Rajbansi, 2012). They belong to 11 orders, 34 families and 104 genera. Similarly, Shrestha (2012) reported 228 indigenous fishes which belong to 11 orders, 32 families, 24 sub-families, and 99 genera including 15 endemic species. Earlier, Shrestha (2008) described a total of 232 fish species belong to 114 genera under 37 families and 11 orders. Out of 232 species 217 are native to different aquatic systems and remaining 15 species are exotics. Karki (2016) stated that Nepal is rich in fish biodiversity and its aquatic systems support nearly 200 fish species which are commercially and economically important (Gautam, 2015).

Various researchers have reported different numbers of fish species from the Gandaki/ Narayani river system. Amongst them, Shrestha (1981) reported 23 fish species from the Gandaki river system. Edds (1986) recorded 111 species of fish through longitudinal survey of the Kaligandaki-Narayani river system from $100 \mathrm{~m}$ to 3000masl. Further, Smith et al., (1996) reported the presence of 135 fish species from the Narayani river basin below and within the Himalayan foothills. Jha et al. (1989), Dhital \& Jha (2002) collected 68 and 69 species fish from the Narayani-Rapti river system in Chitwan respectively. Furthermore, Shreshta (1990) and Rajbanshi (2002) reported 88 and 85 species from the Narayani River. Similarly, Shrestha (2008) and Rajbanshi (2012) reported the presence of 170 and 195 species respectively from the sapta Gandaki river system and their tributaries from different altitudinal gradient. Jha \& Bhujel (2014) recorded 108 species of fishes from the aquatic resources in Chitwan and adjacent areas in Nawalparasi and Makwanpur districts. In the present collection number of fish species was in increasing trend towards downstream. Edds (1993) reported that longitudinal succession was evident in the Gandaki river. Fish species showed close resemblances with fishes of the different districts of Nepal (Sharma, 2008; Shrestha \& Edds, 2012; Kumar et al., 2015) and also the Ganga river of India (Sarkar et al., 2012).

The carps are dominated group having major food fishes including Labeo spp. Eleven species of Labeo were reported from the Gandaki/Narayani river Shrestha $(2008,2012)$. Only 7 species of Labeo represented in my collection and need further verification. Though fingerlings of different species of Labeo released regularly by Fisheries Research Centre of Nepal Agricultural Research Council in the tributaries of Narayani river to maintain the existing 
stock, only Labeo dero was found abundantly in lower stretches.

The loach Botia lohachata showed its unusual occurrence during sampling, the other three species of this genus were very rare. The Botia geto was collected for the first time from Rapti river (fig. 5). Earlier, Jha \& Bhujel (2014) not reported this species from the Narayani river system. Shrestha $(2004,2008)$ reported 2 and 4 species of the genus Botia respectively from the Gandaki river system. Shrestha (2008) reported the occurrence of Botia geto from the Seti river only. Rajbanshi (2012) also reported B. geto from the Gadaki/Narayani river, but not from the Rapti river in Chitwan and adjacent areas.

The catfishes are important group of fishes represented its dominance after carps. Thirty four species of catfishes were collected from different sampling sites. Shrestha (2008) reported 53 species of catfishes from the Gandaki/Narayani river system out of 70 species from Nepal. About $50 \%$ of total catfishes of Nepal represent in the present collection. Jha (2012) reviewed the Nepalese catfishes and their diversification of aquaculture. Mandal \& Jha (2013) reported the presence of Glyptothorax pectinopterus and Pseudecheneis sulcatus from the Marsyangdi river, a tributary of the Narayani river, in Lamjung district with a total of 26 species. Jha \& Bhujel (2014) not reported the occurrence of Pseudolaguvia ribeiroi (fig. 6) and P. kapuri (fig. 7 ) from the Narayani river system. These species were collected from different parts of the Rapti river (fig. 8, 9, 10). Shrestha (2008) reported both species of the genus Pseudolaguvia from the Gandaki/Narayani river.

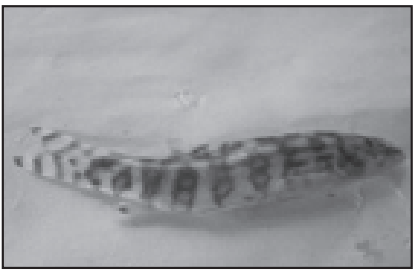

FIG. 5. Botia geto.

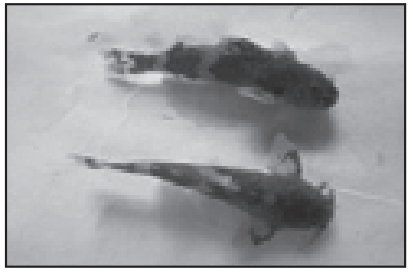

FIG. 6 Pseudolaguvia ribeiroi.

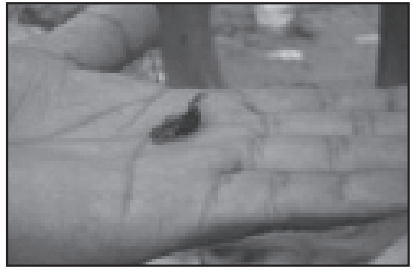

FIG. 7. Pseudolaguvia kapuri

Courtesy: MDI

Edds (2007) reported Glyptothorax Garhwali, Psilorhynchus gracilis, Nangra assamensis, and Sisor rheophilus from the Gandaki/Narayani river. These species were not represented in the collection as Glyptothorax Garhwali and Psilorhynchus gracilis, re ported to occur in the upper reaches of the Kali Gandaki river. Similarly, Nangra assamensis, and Sisor rheophilus reported to occur in the lower most reaches of the Narayani river. Though Sisor rhabdophorus was of rare occurrence in upper reaches of the Narayani river in Chitwan, it was uncommonly seen down from the Gandak barrage. Shrestha $(2008,2012)$ reported both of these species from the Gandaki/Narayani river. Also, $\mathrm{Ng}$ (2003) reported the rare occurrence of Sisor rheophilus from the upper stretches of the Narayani river. Further, 4 and 3 species of Pseudecheneis were reported by Shrestha $(2008,2012)$. The single species of Pseudecheneis sulcatus was represented the collection obtained during this study. On the paper of $\mathrm{Ng}$ and Edds (2005), Shrestha (2012) opined that $P$. sulcatus has been divided in to three different species as $P$. crassicauda, P. eddsi, and P. serracula from Nepal. Also, $\mathrm{Ng}$ and Edds (2005) reported that 
P. sulcatus is restricted to Brahmaputra drainage only, while Shrestha (2008) reported the occurrence of all 4 species from Nepal including $P$. sulcatus. The river shad Gudusia chapra reported earlier from the middle part of Chitwan was collected from lower part only. The distribution of different species of fishes in Chitwan and adjacent areas showed similarities with those of earlier reports (Edds, 1993; Sharma, 2008; Shrestha, 2008; Shrestha \& Edds, 2012; Jha \& Bhujel, 2014).

The Narayani River has a barrage to control water for irrigation and power generation without any fish way has great impact on the ichthyofauna of upstream and downstream of the river. Faunal composition is affected by interference on the natural system of the river, thus development of suitable technology for conservation of indigenous fishes would be challenging (Rajbanshi, 2002, 2012; Gubhaju, 2012, Gurung, 2012). Specially, during spring and summer, downstream near barrage is completely dry, which effect the migration of important migratory fishes. Fishing community of Tribenighat reported declining catches due to degradation of fish habitats and barrage without fish-way which obstruct spawning migration also. Regulation of water flow by damming or irrigation has pronounced effect on fishery resources of major rivers (Shrestha, 2008; Gubhaju, 2012; Mandal \& Jha, 2013).

Though restocking of some important fishes are regularly carried on by Nepal Agricultural Research Council for conservation and maintaining population, more research is needed on whether there are any significant anthropogenic effects on the fish population through habitat alterations, poisoning and other illegal fishing, overexploitation and new species introduction in the river system. Maximum presence of 195 species of indigenous fishes reported from the Sapta Gandaki/ Narayani river system on the basis of literature reviewed, which are either based on the previous works or on short studies by various authors, there is an urgent need of year round studies on the diversity and distribution of different fishes from all tributaries of the Narayani/ Rapti river systems in Chitwan and adjacent areas. The species collected should be preserved and deposited in proper places for further study to avoid confusion.

The study revealed that ichthyofauna in the Trisuli, Rapti and Narayani river systems in Chitwan district and adjacent areas is represented by 111 species which belonged to 9 orders, 27 families, and 72 genera. Among the collected species, order, Cypriniformes had the highest number of species while Anguiliformes, Beloniformes, Clupeiformes and Tetraodontiformes represented the lowest in number. Findings of this study will be useful to ichthyologist and others studying Asian/ South-Asian fishes as well as managers/planners responsible for conserving the existing fauna through aquaculture diversification. Fish diversity of the major tributaries of Narayani river system in Chitwan and adjacent areas was found to be affected by overexploitation of fishery resources and loss of habitat. Therefore, appropriate measures should be applied for species conservation.

\section{ACKNOWLEDGEMENTS}

The author is thankful to fishermen for their help during field survey and collection. The author expresses his gratitude to Mr. Khop Narayan Shrestha, Director of Manahari Development Institute (MDI) for logistic support during fish collection from Eastern Chitwan and adjacent area of Makwanpur districts. Similarly, the author is also indebted to Prof. Dr. D. R. Dangol for constant encouragements. 


\section{REFERENCES}

DHITAL, R R; JHA, D K (2002) Fish fauna of the Narayani river system and their impact on the fishermen communities in Chitwan, Nepal. In PETER, T; SWAR, D B (eds) Cold water fishes of Trans-Himalayan countries. FAO Fisheries Technical Paper No. 431. FAO, Rome, Italy; pp 119-128.

EDDS, D R (1986a) The fishes of Royal Chitwan National Park. Journal of Natural History Museum 10 : $1-12$.

EDDS, D R (1986b) Fishes of the Kali Gandaki/Narayani river, Nepal. Journal of Natural History Museum 10: 13-22.

EDDS, D R (1993) Fish assemblage structure and environmental correlates in Nepal's Gandaki river. Copeia 1993 (1): 48-60.

EDDS, D R.; NG, H H (2007) Additions to the ichthyofauna of Nepal, with a re-description of Neoeucirrhichthys maydelli (Teleostei: Cobitidae). Ichthyol Explor Freshwaters 18(2): 125-132.

GAUTAM, N (2015) Challenges of freshwater fisheries in Nepal: a short overview. International Journal of Applied Sciences and Biotechnology 3(4): 579-583.

GUBHAJU, S R (2012) Impact of damming on the environment of flow and persistence of native fishes. In WAGLE, S K; PRADHAN, N (eds) Proceedings of consultative workshop on fish conservation in Nepal. Fisheries Research Division, Godawari, Lalitpur, Nepal; pp 79-93.

GURUNG, T B (2012) Native fish conservation in Nepal: challenges and opportunities. Nepalese Journal of Biosciences 2: 71-79.

GURUNG, T B (2016) Role of inland fishery and aquaculture for food and nutrition security in Nepal. Agriculture \& Food Security 5:18.

JAYARAM, K C (1999) The fresh water fishes of the Indian region. Narendra Publishing House, New Delhi, India; $551 \mathrm{pp}$.

JHA, D K; BHUJEL, R C (2014) Fish diversity of Narayani river system in Nepal. Nepalese Journal of Aquaculture and Fisheries 1: 94-108.

JHA, D K (2012) Indigenous catfishes and their diversification for Aquaculture. In WAGLE, S K; PRADHAN, $\mathrm{N}$ (eds) Consultative workshop on fish conservation in Nepal. Proceedings of the consultative workshop on fish conservation in Nepal Fisheries Research Division, Godawari, Lalitpur, Nepal; pp 121-131.

JHA, D K; SHRESTHA, M K; RAI, S C (1989) Fish fauna of the Narayani and Rapti river systems in Chitwan, Nepal. Journal of Institute of Agriculture and Animal Science 10: 97-107.

KARKI, N P (2016) Fish farming in Nepal: trends, opportunities and constraints. Nepalese Journal of Agricultural Sciences 14: 201-210.

KUMAR, P; VERMA, S K; SUBBA, B R (2015) Fishes of eastern Terai of Nepal. Journal of Biological, Pharmaceutical and Chemical Research 2(3): 1-5.

MANDAL, R B; JHA, D K (2013) Impacts of damming on Ichthyofaunal diversity of Marshyangdi River in Lamjung district, Nepal. Our Nature 11(2): 168-176.

NG, H H (2003) A revision of the south Asian sisorid catfish genus Sisor (Teleostei: Siluriformes). Journal of Natural History 37: 2871-2883.

NG, H H; EDDS, D R (2005) Two new species of Pseudecheneis, rheophilic catfishes (Teleostei: Sisoridae) from Nepal. Zootaxa 1047: 1-19. 
RAJBANSHI, K G (2012) Biodiversity and distribution of fresh water fishes of central/Nepal Himalayan region. Nepal Fisheries Society in collaboration with RAJBANSHI, B G; RAJBANSHI, P S, Kathmandu, Nepal.

RAJBANSI, K G (2002) Zoogeographical distribution and the status of cold water fishes of Nepal. In. Peter, T; Swar, D B (eds) Cold water fishes of Trans-Himalayan countries. FAO Fisheries Technical Paper No. 431, FAO, Rome, Italy; pp 221-246.

SARKAR, U K; PATHAK, A K; SINHA, R K; SIVAKUMAR, K; PANDIAN, A K; PANDEY, A; DUBEY, V K; LAKRA, W S (2012) Freshwater fish biodiversity in the River Ganga (India): changing pattern, threats and conservation perspectives. Review of Fish Biology and Fisheries 22: 251-272.

SHARMA, C M (2008) Freshwater fishes, fisheries, and habitat prospects of Nepal. Aquatic Ecosystem Health \& Management 11(3): 289-297.

SHRESTHA, J (1981) Fishes of Nepal. Kathmandu, Nepal: Curriculum Development Center, Tribhuvan University, Kathmandu, Nepal.

SHRESTHA, J (1994) Fishes, fishing implements and methods of Nepal. M. D. Gupta, Lalitpur Colony, Laskar, India.

SHRESTHA, J (2001) Taxonomic revision of fishes of Nepal. In. JHA, P K; BARAL, S K; KARMACHARYA, S B; LEKHAK, H D; LACOUL, P; BANIYA, C B (eds) Environment and agriculture: biodiversity, agriculture and pollution in south Asia. Ecological Society (ECOS), Kathmandu, Nepal; pp 171-180.

SHRESTHA, J (2012) Threat status of indigenous fish species of Nepal. In WAGLE, S K; PRADHAN, N (eds) Consultative workshop on fish conservation in Nepal. Proceedings of the consultative workshop on fish conservation in Nepal.. Fisheries Research Division, Godawari, Lalitpur, Nepal; pp 25-48.

SHRESTHA, O H; EDDS, D R (2012) Fishes of Nepal: mapping distributions based on voucher specimens. Emporia State Research Studies 48 (2): 14-21.

SHRESTHA, T K (1990) Resource ecology of the Himalayan waters. Curriculum Development Center, Tribhuvan University, Kathmandu, Nepal.

SHRESTHA, T K (2004) Conservation and management of fish in large rivers of Nepal. In NATH, S (ed) Recent advancement in fish ecology limnology and eco-conservation, Vol VII 1-24. Narendra Publishing House, New Delhi, India.

SHRESTHA, T K (2008) Ichthyology of Nepal. Himalayan Ecosphere; Katmandu, Nepal; 389 pp.

SINGH, A M (2013) An integrated approach for long term solutions of flooding: a study of the eastern Chitwan valley. Hydro Nepal 12: 66-75.

SMITH, B D; BHANDARI, B; SAPKOTA, K (1996) Aquatic biodiversity in the Karnali and Narayani river basins-Nepal. IUCN Nepal.

TALWAR, P K; JHINGRAN, A G (1991) Inland fishes of India and adjacent countries, Vol. I \& II. Oxford and IBH publishing Co. Pvt. Ltd, New Delhi, India. 